\title{
Tetraplasandra lydgatei (Araliaceae): Taxonomic Recognition of a Rare, Endemic Species from $\mathrm{O}^{\top} \mathrm{ahu}$, Hawaiian Islands ${ }^{1}$
}

\author{
Timothy 7. Motley ${ }^{2}$
}

\begin{abstract}
Tetraplasandra is a genus of seven species endemic to the Hawaiian Archipelago. Recent field studies in the Ko'olau Mountains on the island of O'ahu have led to a taxonomic reevaluation of a rare species, Tetraplasandra lydgatei. The species, originally described in the late 1800 s, was placed into the widespread, polymorphic species T. oabuensis in a subsequent treatment of the genus. Several morphological characters and varying ecological habitats distinguish the two species. Based on these differences T. lydgatei deserves formal taxonomic recognition. Furthermore, T. lydgate $i$ was an uncommon species even when it was originally described. This may be due to the early human alteration of the dry and mesic Hawaiian forests for housing and agriculture and also that the species was always only an occasional component of the mesic ecosystem. Regardless of the reasons, the rarity of this species has been accelerated. Currently, only six individuals of T. lydgatei are known to exist, and conservation efforts to protect it are needed.
\end{abstract}

The Hawailan endemic genus Tetraplasandra A. Gray as currently circumscribed contains seven species (Lowry 1990, Lowry and Wood 2000). Tetraplasandra lydgatei (Hillebr.) Harms was first described by Hillebrand (1888) as Triplasandra lydgatei; the genus Triplasandra Seem. was later subsumed into Tetraplasandra (Harms, 1898). Subsequently, Lowry (1990) combined T. lydgatei with the polymorphic, widespread species T. oahuensis (A. Gray) Harms, believing that $T$. lydgatei represented simply a morphological extreme in the wide range of variation encompassed among individuals of T. oabuensis. The Lowry (1990) treatment represents a more concise and workable taxonomic framework for the genus based on current data and knowledge about the ranges of species variation in the Hawaiian Islands

${ }^{1}$ Financial support provided by the Lewis B. and Dorothy Cullman Foundation. Manuscript accepted 24 May 2004.

${ }^{2}$ The Lewis B. and Dorothy Cullman Program for Molecular Systematics Studies, The New York Botanical Garden, Bronx, New York 10458.

Pacific Science (2005), vol. 59, no. 1:105-110

(C) 2005 by University of Hawai'i Press

All rights reserved in which many of the more than 82 species, subspecies, and varieties described in, and subsequent to, Sherff's (1955) revision of the genus were synonymized. However, extensive field investigations by botanists John Obata and Ron Fenstemacher over many years have led them to suspect that one lowland species, T. lydgatei, still warranted taxonomic recognition based on habitat and several morphological characteristics.

During my field investigations in 1995 and 1996 with Obata and Fenstemacher they identified the localities of two known Tetraplasandra individuals that they determined to be morphologically distinct from T. oabuensis. On revisiting the sites one of the two individuals had died since their last visit. The single living individual was found at an elevation of $335-340 \mathrm{~m}$, which is typically lower than the usual range for T. oabuensis $(>500 \mathrm{~m})$ in the Ko'olau Mountain Range of O'ahu. In addition, the leaves of the individual were more membranous than the coriaceous leaves of $T$. oahuensis, but based on a single sterile individual the variation was attributed to the ecological habitat. However, in late July 1996 the plant began to flower. Even in bud the inflorescences were very distinct from those of $T$. oabuensis and it became clear that this was a unique species, morphologically 
similar to prior scientific descriptions and type specimens of $T$. lydgatei. Later, senescent flowers and fruit became available for study and supplied further characters to distinguish the taxon from the other species of Tetraplasandra.

The realization also struck us that the extinction of this species was imminent and the preservation of the species may require an actual resurrection rather than taxonomic resurrection. This concern spurred additional field exploration and surveys by Daniel Chun and other botanists that led to the discovery of seven additional individuals, two of which have since died. One of these flowered and fruited profusely before perishing and provided further material for this study and propagation. Currently, there are six known individuals of $T$. lydgatei in the southeastern Ko'olau Mountains; I have seen three of these.

Phylogenetic analyses of sequences from the nuclear ribosomal Internal Transcribed Spacer (ITS) and 5S nontranscribed spacer (Costello and Motley 2001) did not provide resolution among members of the Tetraplasandra oabuensis clade (T. oabuensis, T. lydgatei [not included in ITS], T. waimeae Wawra, and $T$. waialealae Rock), but this is not uncommon in closely related Hawaiian plant lineages (Ganders et al. 2000, Gemmill et al. 2002, Lindqvist and Albert 2002). The use of Amplified Fragment Length Polymorphisms (AFLP) has been useful for providing additional resolution among taxa resulting from recent and rapid species radiations (Lindqvist et al. 2003). In a recent AFLP study of the
Tetraplasandra group (Costello and Motley 2003) the members of the T. oabuensis clade (plus, on the recommendation of Timothy Flynn, National Tropical Botanical Garden, an individual thought to represent T. bisattenuata Sherff $[=T$. oabuensis $]$ ) formed a polytomy. One clade contained three individuals of $T$. lydgatei that were resolved as sister to $T$. waimeae and T. waialealae. A second clade included eight individuals of T. oahuensis sampled from throughout the Hawaiian Islands. The T. bisattenuata individual and a $T$. oabuensis individual from the Wai'anae Mountains, O'ahu, were unresolved. This AFLP evidence provides further support for the segregation of $T$. lydgatei from T. oabuensis.

Morphologically it is difficult to find diagnostic characters to separate species of this clade from the polymorphic T. oabuensis without using overlapping or continuous characters. Tetraplasandra waimeae and $T$. waialealae are separated dichotomously from T. oabuensis in the key of the recent treatment (Lowry 1990) by their larger fruit size and inflorescences without bract scars (which occasionally do occur in T. waimeae).

In the taxonomic key in the Manual of the Flowering Plants of Hawai i, T. lydgatei can be segregated from the other species of the genus (including T. flynnii, which was not treated) by: inflorescences strictly compound umbellate (second choice in couplet 1); rays of inflorescence with 1 to several bract scars (couplet 5[1]). This keys the species as $T$. oabuensis. These two species can be separated by the following couplet.

Fruit cylindrical, occasionally ovoid, 7-15 mm long; leaves coriaceous; flower petals pinkish red to yellow green; nectary disk pinkish red, peduncles $3.5-10 \mathrm{~mm}$ wide, pedicels $\geq 1.5$ $\mathrm{mm}$ wide; terminal umbellules of flowers flat-topped to convex, with outer pedicels pro-

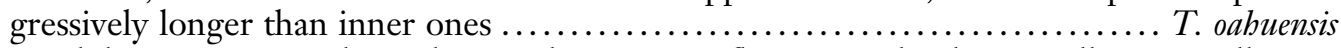

Fruit globose, 4-5 mm long; leaves chartaceous; flower petals always yellow to yellow green (never pink or red); nectary disk yellow; peduncles $\leq 2 \mathrm{~mm}$ wide; pedicels $\leq 1$ $\mathrm{mm}$ wide; terminal umbellules of flowers spherical, with pedicels being nearly equal in

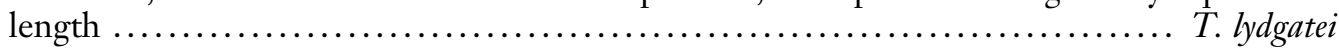

Tetraplasandra lydgatei (Hillebr.) Harms Harms, 1898, in Engl. \& Prantl, Pflanzenfam. III, 8:20; Triplasandra lydgatei Hillebr., 1888, Fl. Hawaiian Isl., p. 153. Type: "Wailupe, Isl. Oahu," Rev. Fobn M. Lydgate s.n. (holotype, formerly at в [destroyed]; isotype, BISH 488665! [fragment]; possible isotype, "Niu or Wailupe," Isl. Oahu, W. Hillebrand of 7. M. Lydgate s.n. віsн 488664!). synonomy: Tetraplasandra lydgatei var. 
bracbypoda Sherff, 1952, Bot. Leafl. 6:19. Type: "Niu valley, wooded valley, tree 30-40 tall," Isl. Oahu, 3 Dec. 1933, D. L. Topping \& $W$. Bush 3,701 (Ny 00217978!, holotype; Mo, NY [three sheets]!, isotypes); T. l. var. coriacea Sherff, 1952, Bot. Leafl. 6:21. Type: "Halawa Valley Ridge Trail, 1800 ft., Koolau Range, Southeastern Oahu," 2 Mar. 1947, S. Cowan 563 (віSн 488744! holotype; віSн 488745! isotype); T. l. var. forbesii Sherff, 1952, Bot. Leafl. 6:20. Type: "tree about $20 \mathrm{ft}$. tall, darkish bark, leaves with 7 leaflets ... turning yellow with age ... ridge west of Waialae Valley, near the top, rather dry locality," Isl. Oahu, 15 Oct. 1914, C. N. Forbes 1942-O (us, holotype; вISH 4887433!, 488748!, isotypes); $T$. l. var. leptorbachis Degener \& Sherff, 1952, Bot. Leafl. 6:20. Type: "open, windy rainforest, slope north-east of Nuuanu Valley," Isl. Oahu, 20 Nov. 1926, Degener 17, 796 (us, holotype; мо, NY [three sheets]!, isotypes); Triplasandra lydgatei Hillebr.

Description: Trees 7-10 m tall. Leaves 34-40 (50) cm long, leaflets (7) 9-11, broadly elliptic or ovate to oblong-elliptic, lateral ones often slightly falcate, 7-9 cm long, 3-3.5 $\mathrm{cm}$ wide (lower pair often smaller), glabrous, apex rounded, base rounded to attenuate, margins slightly revolute, petiolules $1-2 \mathrm{~mm}$ long. Flowers in erect, 2 times compound umbel, primary axis $0.6 \mathrm{~cm}, 9-12$ secondary axes, $8-10 \mathrm{~cm}$ long with one to several bract scars, each with a terminal, spherical umbellule of 26-47 flowers, pedicels $1.5-3 \mathrm{~cm}$ long, becoming slightly curved in fruit; calyx lobes undulating, becoming acute in fruit, $<1 \mathrm{~mm}$; petals six, ovate, $2 \mathrm{~mm}$ long, $1 \mathrm{~mm}$ wide, yellow to yellow green; stamens 12 or 18 (two to three times as many as petals), in a single whorl; ovary fully inferior, (3)-4 celled. Fruit $1 \mathrm{~cm}$ long, $0.5-0.7 \mathrm{~cm}$ wide, globose to ovoid with stylopodium forming small $(1 \mathrm{~mm})$ beak, fruit wall becoming longitudinally ridged when dry. Seeds globose, 4-5 mm long.

Distribution: Rare, in mesic forest of the Ko'olau Mountain Range, southeastern O'ahu. Formerly, ranging from Niu Valley to the Hâlawa Ridge trail, 335-548 m; the distribution currently appears to be limited to the eastern slopes of Hawai'i Loa and Kūlepeamoa Ridges, 335-378 m.
Phenology: The phenological data are limited, but it appears that the reproduction of the species is not on an annual cycle. Flowering tends to occur in the summer months as early as June and peaking JulySeptember. Fruit remains on the tree from September to January, with records extending until March; maturation takes 3-4 months.

SPECIMENS EXAMINED: Hawaiian Islands, island of $\mathrm{O}^{\prime} \mathrm{ahu}$ : "Western slope of central ridge of Niu Valley, moderately open, dry summit," 4 June 1932, O. Degener 18,244 (Ny); "Wahiawa," 25 Nov. 1926, O. Degener s.n. (NY); "Hawaii Loa Ridge, E. facing slope, 335 m." 15 Dec. 1997, T. Motley 1809 (NY); "same individual 1809," 18 Aug. 1997, T. Motley \& R. Fenstemacher 1798.5 (NY); "same individual 1809," 1 Oct. 1998, T. Motley \& R. Fenstemacher 2025 (NY); "Hawaii Loa Ridge, down in Pia Gulch, by wire on trail, small tree," 3 Oct. 1998, T. Motley, R. Fenstemacher \& J. Obata 2032 (NY); "same locality 2032, large tree farther down slope," 3 Oct. 1998, T. Motley, R. Fenstemacher \& 7. Obata 2033 (NY); "Palolo-Waialae ridge," 27 Jan. 1927, L. H. MacDaniels 466 (віSн); "Koolau Range, Hawaii Loa Ridge, 335 m, off ridgetop in subgulch, $1 \mathrm{~km}$ from beginning of trail, E-facing, w/Psidium; trunk erect, narrow, no branching before $2.5 \mathrm{~m}$; leaflets ... chlorotic-looking turns green when drying, ... stamen 18-21," 27 Sept. 1992, 7. Obata \& R. Fenstemacher s.n. (вІSн, two sheets), "Koolau Range, Aina Haina, Kului-Wailupe Ridge, $335 \mathrm{~m}$ elev., along ridgetop, growing under Psidium sp. (waiawi) in drier steep habitat. Inflorescences in bud, leaves atypical T. lydgatei, more leaflets, possibly T. oahuensis," 2 Aug. 1992, 7. Obata \& R. Fenstemacher s.n. (вІSH); "Ridge between Niu and Wailupe," 11 Apr. 1917, C. N. Forbes \& 7. C. Bidwell 2461-O (віsн); "Wailupe Valley," 4 May 1917, C. N. Forbes 2511-O (вISH); "Niu Valley, in moderately dry open woods on side of the trail on western slope of central ridge of $\mathrm{Niu}$, same tree as Topping Bush No. 3701," 4 June 1932, O. Degener, O. Sweeny, K. Parks \& Y. Nitta 6099 (віSн), "Hawaii Loa ridge, same place as 14-June2000 collection," 30 July 2000, D. Chun s.n. (віsн, two sheets and alcohol collection). 


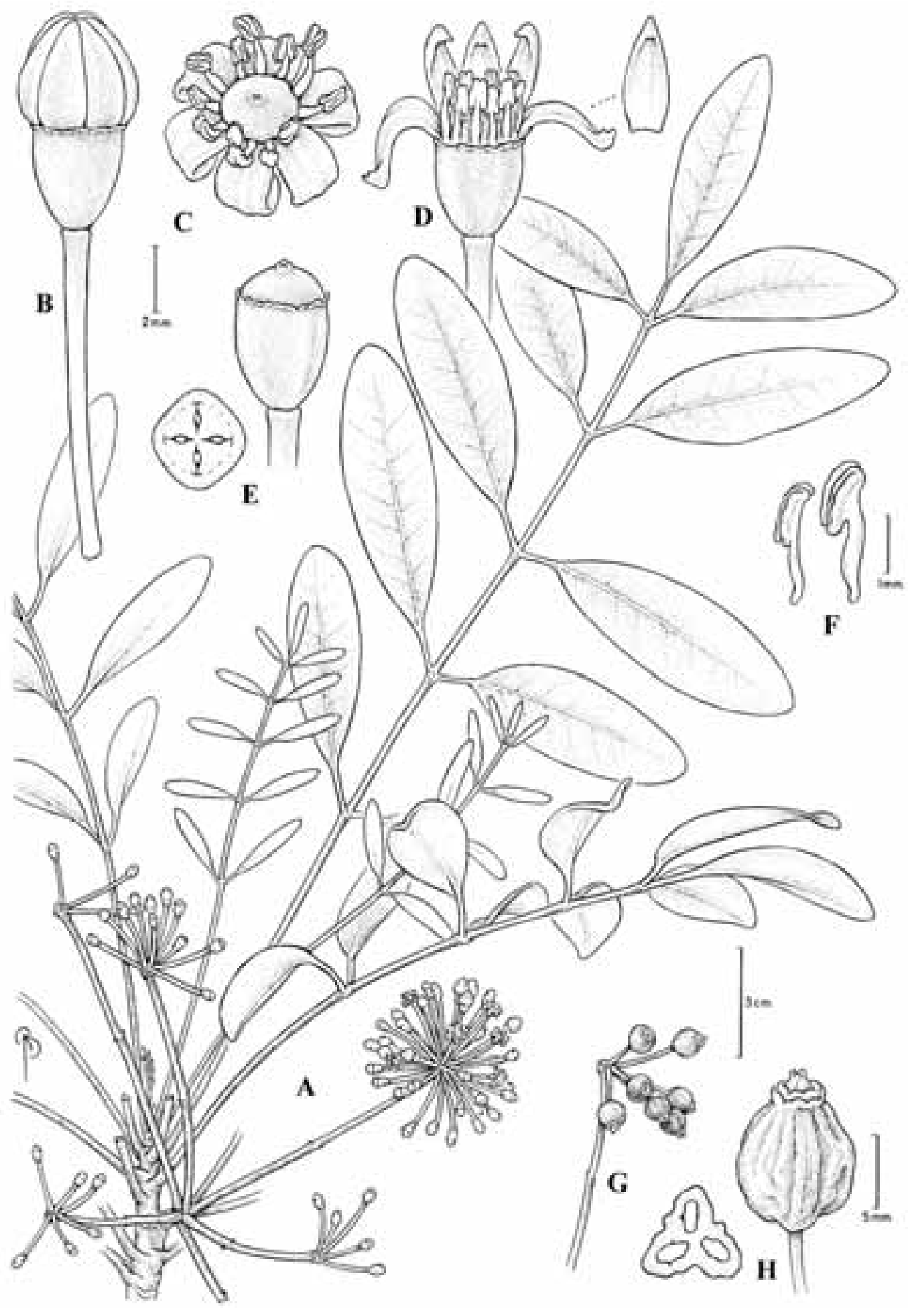

Figure 1. Tetraplasandra lydgatei (Hillebr.) Harms. $A$, Terminal branch with inflorescence; $B$, individual flower bud; $C$, dorsal view of flower at anthesis; $D$, lateral view of flower with sepal removed; $E$, immature fruit and cross section; $F$, stamen; $G$, infructescence; $H$, mature fruit and cross section. 
Collection originally identified as T. lydgatei is a misdetermined T. oabuensis: "Waialae Nui Ridge, single large tree in rainforest, alt. 2,200 ft," 2 Oct. 1949, O. Degener \& C. Nibei 20,222 (BISH, NY).

\section{DISCUSSION}

Tetraplasandra lydgatei is a distinct species inhabiting the mesic Hawaiian forest remnants of the southeastern Ko'olau Mountains. The compound umbels and presence of bract scars on the inflorescence rays distinguish this taxon from most other members of the genus (Figure 1), excluding the widespread, polymorphic species T. oahuensis. The two species are very closely related (Costello and Motley 2001), but a combination of floral and fruit characters distinguishes the taxa (Table 1). Furthermore, the taxa seem to share different elevation habitats, with $T$. lydgatei typically occupying forest below $500 \mathrm{~m}$ and $T$. oabuensis inhabiting the higher, wet forest.

The mesic forest habitat of T. lydgatei, unfortunately, is now dominated by two invasive weed species, Psidium cattleianum Sabine (strawberry guava) and Schinus terebintbifolius Raddi (Christmas berry), which form dense stands that outcompete native species and shade out understory growth. Native trees occasional in the habitat include Santalum freycinetianum var. freycinetianum
Gaud., Acacia koa A. Gray, Pouteria sandwicensis (A. Gray) Baehni \& Degener, Bobea sandwicensis (A. Gray) Hillebr., Pittosporum confertiflorum A. Gray, Eugenia reinwardtiana (Blume) DC, Psydrax odorata (Forst. f.) A. C. Smith \& S. Darwin, Myrsine sandwicenis A. DC, Nesoluma polynesicum (Hillebr.) Baill., Sapindus oahuensis Hillebr. ex. Radlk., and Diospyros sandwicensis (A. DC) Fosb. Understory species are Alyxia oliviformis Gaud., Chamaesyce arnottiana (Endl.) Degener \& I. Degener, and the federally endangered fern Diellia erecta Brack. Regeneration of the native species in this area seems very limited. No saplings or seedlings have been seen of $T$. lydgatei or the other native tree species in the area, with the exception of $A$. koa. The Hawaiian mesic forest species, particularly in the Ko'olau Mountain Range, are quickly disappearing.

Conservation measures to protect $T$. lydgatei are needed because the current, known population is reduced to six individuals. However, it seems that even in the 1930s this taxon was not common. Degener noted on several of the specimens cited here that the plant was "extremely rare." Indeed it appears that many of the collections were made from the same individual during separate collecting trips, and very few herbarium collections of the species exist. Seeds from the trees germinate readily; however, the seedlings require specific treatment for survival. Young plants

TABLE 1

Comparison of Morphological Characters between T. lydgatei and T. oabuensis

\begin{tabular}{|c|c|c|}
\hline Character & Tetraplasandra lydgatei & Tetraplasandra oabuensis \\
\hline Leaves & Chartaceous & Coriaceous \\
\hline Petals & 6 , yellow to yellow green & $5-7(8)$, pinkish red to yellow green \\
\hline Nectary disks & Yellow & Pinkish red \\
\hline Stamens & 12 or 18 & $5-25-(30)$ \\
\hline Carpels & (3) -4 & $3-8$ \\
\hline Fruits & Globose, 4-5 mm long & Cylindrical to ovoid, 7-15 $\mathrm{mm}$ long \\
\hline Inflorescences & Compound umbel, $2 \mathrm{x}$ compound & $\begin{array}{l}\text { Compound umbel or racemose umellate, } 2-3 \mathrm{x} \\
\text { compound }\end{array}$ \\
\hline Peduncles & Slender, $\leq 2 \mathrm{~mm}$ wide, $8-10 \mathrm{~cm}$ long & $\begin{array}{l}\text { Slender to robust, } 3.5-10 \mathrm{~mm} \text { wide, } 7-15-(18) \\
\mathrm{cm} \text { long }\end{array}$ \\
\hline Pedicels & Slender, $\leq 1 \mathrm{~mm}$ wide, $15-30 \mathrm{~mm}$ long & $\begin{array}{l}\text { Slender to robust, } \geq 1.5 \mathrm{~mm} \text { wide, } 6-18-(22) \\
\text { mm long }\end{array}$ \\
\hline Umbellules & Spherical & Mostly flat-topped or convex, rarely spherical \\
\hline
\end{tabular}


must be kept in full shade if the soil is kept moist, or if kept in partial sun the soil should not be moist. Seedlings placed in the sun with moist soil quickly die, perhaps due to the creation of conditions promoting soil pathogens (Daniel Chun, pers. comm.). In addition, plants have been propagated through micropropagation at the Lyon Arboretum, but plants transplanted out of media culture have not survived perhaps due to the wet conditions in Mānoa Valley (Nellie Sugii and Elizabeth Huppman, pers. comm.). It is possible that cultivation and outplanting will be a successful way to preserve the species; however, reforestation efforts and the success of offspring among the dense stands of Psidium cattleianum seem bleak without active management.

\section{ACKNOWLEDGMENTS}

I thank Daniel Chun, Roland Fenstemacher, Elizabeth Huppman, John Obata, and Nellie Sugii for assistance in the field and for information about the distributions, phenology, and/or cultivation of T. lydgatei. I also thank Kobi Abdul-Salim, Derrel Herbst, Clyde Imada, Larry Kelley, Robbin Moran, and George Staples for taxonomic discussions. I also thank the herbarium staff at the Bernice P. Bishop Museum and The William and Lynda Steere Herbarium for assistance and access to collections and Bobbi Angel for the scientific illustration. I acknowledge Tatyana Lobova and two anonymous reviewers for the helpful comments and suggestions on the manuscript. I also thank The Lewis B. and Dorothy Cullman Foundation for financial support.

\section{Literature Cited}

Costello, A., and T. J. Motley. 2001. Molecular systematics of Tetraplasandra, Munroidendron, and Reynoldsia sandwicensis (Araliaceae) and the evolution of superior ovaries in Tetraplasandra. Edinb. J. Bot. 58:229-242.

- 2003. Phylogenetic relationships within the Tetraplasandra group (Araliaceae) revealed by Amplified Length Polymorphisms (AFLP) markers. Page 76 in Botany 2003 Abstracts (http://www. 2003.botanyconference.org).

Ganders, F. R., M. Berbee, and M. Pirseyedi. 2000. ITS base sequence phylogeny in Bidens (Asteraceae): Evidence for the continental relatives of Hawaiian and Marquesan Bidens. Syst. Bot. 25:122-133.

Gemmill, C. E. C., G. L. Allen, W. L. Wagner, and E. A. Zimmer. 2002. Evolution of insular Pacific Pittosporum (Pittosporaceae): Origin of the Hawaiian radiation. Mol. Phylogenet. Evol. 22:31-42.

Harms, H. 1898. Araliaceae. Pages 1-62 in Engler and Prantl's Die Naturlichen Pflanzenfamilien, III. 8. Dunker and Humbolt, Berlin.

Hillebrand, W. F. 1888. Flora of the Hawaiian Islands. Pages 151-154. Lubrecht \& Cramer, New York.

Lindqvist, C., and V. A. Albert. 2002. Origin of the Hawaiian endemic mints within North American Stachys (Lamiaceae). Am. J. Bot. 89:1709-1724.

Lindqvist, C., T. J. Motley, J. J. Jeffery, and V. A. Albert. 2003. Cladogenesis and reticulation in the Hawaiian endemic mints (Lamiaceae). Cladistics 19:480-495.

Lowry II, P. P. 1990. Tetraplasandra. Pages 232-237 in W. L. Wagner, D. R. Herbst, and S. H. Sohmer, Manual of the Flowering Plants of Hawai'i. University of Hawai'i Press/Bishop Museum Press, Honolulu.

Lowery II, P. P., and K. R. Wood. 2000. A new, threatened species of Tetraplasandra (Araliaceae) from Kaua'i, Hawaiian Islands, and notes on its conservation status. Novon 10:40-44.

Sherff, E. E. 1955. Revision of the Hawaiian members of the genus Tetraplasandra A. Gray. Fieldiana Bot. 29 (2): 49-142. 